\title{
Passing on, and Passing on Wealth: Compelling Values in Tongan Exchange
}

\author{
Ping-Ann Addo
}

\section{Introduction: A life adorned with koloa}

Throughout her life, Kalo has always been intimately involved with koloathe textiles that comprise the most important category of traditional wealth for people from the Kingdom of Tonga. One of five sisters and one brother, Kalo grew up in Vava'u, Tonga, learning everything about koloa that her mother could teach her. After all of her sisters married and moved away from the family home-two of them moving as far away as Auckland, New Zealand-Kalo remained her mother's ardent supporter in the making, caring for, gifting, receiving and sorting of koloa. In this chapter, I examine the ways in which koloa is integrated into Kalo's end of life experience as she transitions into becoming an ancestor. Taking a retrospective and introspective outlook, as Kalo herself did in conversations I had with her in early 2012, I examine the meanings of women's wealth across generations and changing social contexts for Tongans in diaspora.

Tongans have long honoured people of status in their communities with gifts of koloa, accompanied by food and, more recently, by cash. The wife of a Methodist church pastor, Kalo's mother had, over the course of her 
married life, received and reciprocated innumerable pieces of koloa from people in their community. Having never married, Kalo lived at home and helped her mother with these tasks until the older woman died in the early 1970s. Then Kalo succeeded in caring for her mother's koloa herself, contributing it to collective gifts and life crisis celebrations in her käinga, or extended family. In 1978, when she moved to Auckland to join her younger sister who had lived there for several years, Kalo took several of her mother's much-loved koloa as part of the wealth she would use to continue the cultural tradition of ceremonial gifting, or fai fatongia. When I met Kalo in 2000, she lived alone in a small apartment near her Tongan Methodist church in an Auckland suburb. Kalo's dedication to koloa was expressed throughout her living space. The apartment had three bedrooms, one of which was entirely devoted to the storage of koloa, which included fine mats plaited from pandanus leaves and barkcloth made from both natural and synthetic materials. In the other two bedrooms, beneath the mattresses, lay carefully folded pieces of koloa. Kalo rarely slept on these beds, preferring to sleep on several layers of fine mats on her living room floor. In bags and boxes around her apartment were skeins of coloured yarn and packets of wide-eyed needles for embellishing or fixing the decorative edges on some varieties of fine mats. Sometimes there were containers of leftover dye from a barkcloth-making session stored under her kitchen sink.

Thus, even in diaspora, Kalo continued to adorn her life with koloa, and she ensured that koloa of all types remain intimately connected to the spiritual life of her family. As is the case for many Tongan women, Kalo's involvement with koloa seemed to be inseparable from her devotion to God and her church (Figure 36). Whenever there was a family ritual-a wedding, first birthday, 21st birthday, or christening - it would be celebrated, at least in part, in the Methodist church next door. Kalo's sisters, their children and grandchildren, would first assemble at Kalo's house to prepare for the celebration. They would unfold, sweep, sun and layer appropriate combinations of koloa-usually a fine mat, barkcloth, and a quilt-for presentation to key members of the celebrants' lineages. They would don ta'ovala (waist mat worn wrapped around the hips in formal Tongan dress styles) that Kalo had chosen for each of them over the long-sleeved or long-skirted church outfits, taking Kalo's correction on how to wrap and tie it around their waists with belts made of plaited coconut fibre or braided synthetic hair decorated with coloured beads. 


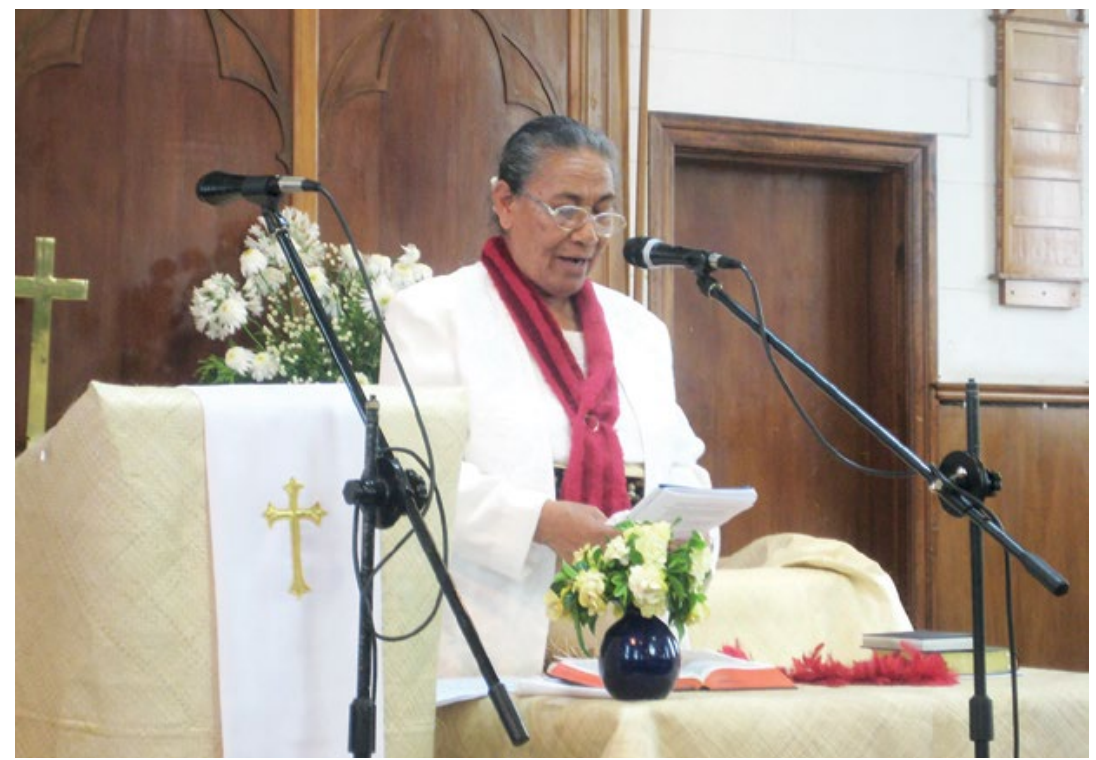

Figure 36. Kalo delivers a sermon at her church. The altar and tables in front and behind her are draped in fine mats

Source. Photographed by Ping-Ann Addo, Auckland, December 2007 and used with Kalo's permission

After the event, the entire family typically returned to Kalo's small house for a cup of tea and some biscuits, or for a more elaborate meal catered by the younger women in the family. Before eating, Kalo would carefully store the koloa that her relatives had worn for future occasions (see Figure 37). Hymnal practices for the family's presentations at special church services were also held in Kalo's small living room. Indeed, her home provided an important venue for the transmission of cultural knowledge and practices regarding koloa.

In 2012, at the age of 78, Kalo moved to live her with 'daughter' 'Ana-a niece whom she had raised. Kalo transitioned from participating in weekly Tongan cultural activities to staying home and reading her Bible, or watching television, but primarily catching up with relatives or friends on the phone. After the move, she ceased many activities that tied her to the broader Tongan community. For example, she no longer held or even attended weekly meetings of her all-women's rotating credit group that had, for years, met every Tuesday in her apartment. In a rotating credit group, members each contribute weekly a set amount of cash, and one member takes home the pool. This rotates until every member has received a payout, and the cycle can stop at that point or continue for 
further cycles. She no longer participated in the textile-making work that had been the most culturally important, shared activity of the women in the rotating credit group. For many years, these women had gathered to embroider pillow cases and decorate fine mats, and when they had money - which they received sometimes from outside funding agencies (see Addo 2013) - they would engage in textile making with materials sourced primarily in New Zealand.

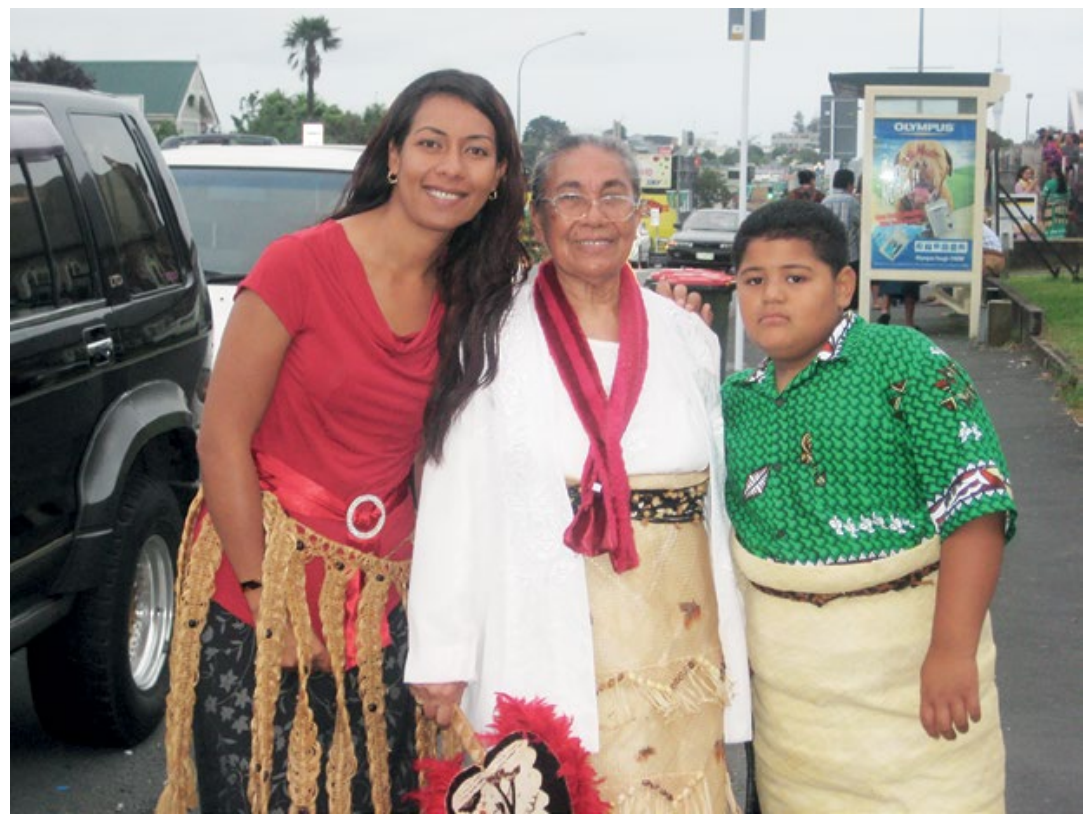

Figure 37. Kalo (centre), her daughter, 'Ana, and great-nephew dressed for the New Year's Day service at their church

Source. Photographed by Ping-Ann Addo, Auckland, December 2007

Thus these women were crucial in the ceremonial lives of their families, but many of them acknowledged that they sought Kalo's advice about choosing koloa. In this sense, Kalo was a special node of connection in the maintenance and transfer of knowledge about and social relations embodied in koloa among diasporic Tongans in New Zealand. Indeed, one day, as Kalo and I sat in her living room, a car pulled up outside and a young man delivered a folded fine mat that his aunt-one of Kalo's counterparts in the textile-making group-charged him with delivering as her thanks to Kalo for her help with arranging koloa for her daughter's recent wedding. 
When I visited Kalo in early 2013, I was shocked to find out that she no longer had any koloa in her possession, save for a few ta'ovala (waist mats) that she wore for church or ritual occasions and a barkcloth and a fine mat she had saved from her own mother. I asked to whom she had given these things and what she received in return:

I gave a few to [friends from the textile-making group] Seilose, Olga and Talita. You remember Talita is my cousin, yes? The koloa that my mother left to me ... I gave some to my sisters. I told Mele, the one after me, which ones I wanted to be buried in when my time comes ... the ta' ovala I am to wear and the one I want my coffin wrapped in. But I took a lot of the koloa to Mele's daughters and to my nieces and gave it to them. I told them how to keep the [mats and barkcloth] folded under their mattresses so they do not wrinkle the faces [of the cloth] ... What did they give me back? Nothing ... But I don't need anything. It's [from] my love.

'Why did you do this?' I wondered out loud, knowing that she had always been the one to have some koloa around. 'I have to leave them something', came her earnest reply. I duly noted that this purposeful detaching of wealth items from herself was an exercise in preparing some sort of bequest for members of younger generations in her käinga. At its root it was about passing on something prestige-laden, tangible and personal to her descendants.

In this chapter, I explore how the notion of koloa as wealth can be borne out in old age for (diasporic) Tongan women as they negotiate their relationships of authority and obligation with younger generations of their kin groups. Objects, like relationships, are not static, and objects embedded in relations between people help us understand what is of value to actors whose modernity-whether deliberately or by proxy-includes traditional wealth items. I analyse how Kalo has used wealth to respond to, but also to redirect, the life course of others in her kin group based on their shared cultural values. She deploys koloa during life crises ceremonies and other moments of transition in order to effect agency in their successful and happy futures-futures that she hopes will be anchored in Tongan culture and tied to Tonga as an ethnic homeland. The meanings of wealth objects are never guaranteed, and are subject to multiple interpretations (Keane 2005). These meanings may change along with the contexts in which individuals, and those most closely related to them, experience the often disruptive effects of life's transition moments. 
I use the lens of koloa in Kalo's life transitions to explore how the specificities of the hopes that Kalo holds for her koloa translate into a range of meanings for the wealth items. I follow Jennifer Johnson-Hanks, who suggests that 'we move away from thinking about transition events as the things that organize socially made lives' and 'instead ... focus on institutions and aspirations, recognizing that these aspirations are multiple, changeable, and apply over a variety of temporal frames' (Johnson-Hanks 2002: 867). Kalo's outlook is one that is at once retrospective and forward looking, which is common in ageing subjects (Albert and Cattell 1994; Counts and Counts 1985). It is a perspective that is worth examining for how we understand objects to embody value and convey meaning, even as value and meaning change over the course of a life. Kalo is an elderly migrant woman who is considering her impending death, but also reflecting on her kin group as one that has a deep and long history, as well as a future as a käinga that identifies, and can be identified, as Tongan. Her aspiration now is to actively infuse her kin-group members' lives with Tongan tradition in the form of sensibilities, practices and icons such as wealth objects.

Through my analysis of koloa as Kalo deploys them in her family relationships, I suggest that the wealth-related aspects of women's valuables can be better understood by examining the life course of women associated with them. The life course 'refers to a sequence of age-graded events and social roles that are embedded in social structure and historical change' (Elder 2001: 8818). A life course perspective thus allows us to consider how different people in a group experience a particular kind of identity project-in this case, how to be demonstrably Tongan-based on their particular age-grade vantage points. Life stories of non-chiefly Tongan women have been published (for example, Fanua 1996), but a life-course perspective is missing from the academic study of Tongan women's wealth. Looking at how commoner women at different points in the course of their lives and in different generations relate through koloa allows us to consider the diverse ways women make wealth meaningful. I go so far as to suggest that the life course includes the experiences and responsibilities a woman expects to have even after she has died. Tongans-the vast majority of whom are Christian faith-keepers-believe in an afterlife as well as in the efficacy of those who have passed on. ${ }^{1}$

1 Ancestors are ever-present members of Tongan families, as exemplified in their visiting those left behind in dreams, their graves being cared for regularly by kin, and the frequent naming of newborn babies after (recently) deceased relatives. Babies and children who are thus named may even be spoken to as if they are the specific ancestor. 
A native Pacific Islander is almost never more authoritative than when she is an ancestor, or close to becoming one. As Dorothy Ayers Counts and David R. Counts (1985) have documented, women in Pacific societies often enjoy increased authority in the public domain on entering 'old age'. This was certainly true of Kalo in the years when I first knew her, and she certainly still retains a strong sense of her own authority vis-à-vis the younger people in her kin group, as well as strong hopes that they will continue to live by Tongan values after she has passed on. However, since she moved in with 'Ana, Kalo seems to have a different relationship with public life, working more behind the scenes to impart knowledge about wealth to her descendants, but also maintaining the authority to compel others to act in particular ways. This authority rests on the status of koloa as wealth-that Kalo's womanhood is framed by a life spent knowing, making and gifting koloa makes her an appropriate agent to declare her hopes to her descendants through such wealth.

\section{Transitions, paths, influences}

Koloa link individuals together into communities. Like so many forms of Oceanic wealth, they are usually exchanged at rituals of transition that matter to lineages and community for their collective history and their self-realisation in the present. Heather Young Leslie states ' $k o l o a$ is redolent with several sets of meanings, including ... locating an individual within a social network that spans generations' (1999: 259). As I show below, koloa have often been important anchors to places and people during transitions in Kalo's life. Indeed, Kalo's life course may be categorised as a bundle of transitions - transitions that were made more manageable by having and deploying koloa.

During the late 1970s, when she was in her mid-40s, Kalo underwent a major transition: she moved from her native Tonga to the city of Auckland, New Zealand. As a member of one of the earliest migrations of commoner Tongans to white-majority nations in the Pacific, Kalo did so-called unskilled work (in a fish canning factory), lived with relatives (two of her sisters who had emigrated before her) and helped raise these relatives' children. At first she merely cared for one particular sister's daughters while living with them in their biological mother's house. However, wishing to live closer to the church that she regularly attended three times a week-as is normal in devout Methodist Tongan families—she applied to her church administrators for permission to rent a small apartment near the church. She moved into the small three-bedroom apartment in the late 1980s. 
This move, effectively, to live in the church's 'backyard', was another key moment of transition for Kalo. She has always been autonomous but, as Tongan women do, she uses that autonomy to benefit her sisters and their kin. ${ }^{2}$

In this little apartment I could take care of my own things. But I couldn't live alone. I asked my sister Mele to let me take [raise] her two eldest ones: Sela and 'Ana. Mela married again, too, and she had just had the baby girl. She was happy to let me take her girls. They lived here with me, they took the bus to school. For a while Amelia [her late sister Tivinia's daughter] lived with us, too (Discussion with Kalo, Auckland, 2001).

Here Kalo raised 'Ana and Sela into adulthood, taking them to church each week, and giving and receiving koloa as their mother at their 16th birthdays and weddings. Today, as women with children of their own, 'Ana and Sela still honour Kalo by referring to her as their 'Mum'. Their own children refer to Kalo as their grandmother, while still remaining close to their biological grandmother, Mele. ${ }^{3}$

During the 25 years that she lived in her apartment, Kalo, being devoutly Christian, attended church three times a week and regularly donated to the church a large portion of her small pension and the money her daughters gave her from their jobs. She also played the role of a 'focalwoman', a term I borrow from Tressa Berman (2003: 83), who refers to 'focalpeople' as those (usually elders) who attain a position of leadership and respect based on consensus by members of their community. In particular, a focalwoman is admired for her exemplary participation in relations of reciprocity, relations that are so often crucial to the economy of indigenous communities. Ever since she moved to Auckland to join her younger sister and to raise children, Kalo had been the focalwoman in her käinga when it came to ceremonial exchange. It has been largely through her efforts to source, store, select and provision others in her kin group with koloa that they have been able to participate in ritual presentations of wealth that many consider especially traditional. She not only advised people about

2 As her brother's older sister, she generally would gain things from, rather than give wealth to, his children. Kalo's brother and his family live in Tonga, so she does not ask for much materially from them. Wealth transfers typically flow from those in the diaspora to their kinspeople in the Kingdom of Tonga.

3 The pusiaki (adoptive) system for raising children guarantees that children know, respect and acknowledge both their biological parents and their social parents. If materially possible, a child will support both sets of parents, but it is not usually considered necessary, as biological parents will probably have other children to support them-they are not likely to have 'given up' the child in the first place if the transaction would leave them childless. 
and arranged koloa, she often donated the cloths they presented, adding her time, advice, leadership and prayers to the collective gift. She did this not only for kin but also for women in her congregation, especially if they were part of her rotating credit association group. Kalo could not remember just how many gifts of combinations of koloa (barkcloth and fine mats, quilts and bedspreads), food and cash she had been part of since she moved to New Zealand, but she had recounted several of these moments over the decade that I had known her.

When both of her daughters, Sela and 'Ana, got married in the late 1980s and 1990s respectively, Kalo presented koloa to the grooms' mothers, their fathers' sisters, and to the pastors who officiated or even just attended the ceremonies. When all of Sela's four children and 'Ana's three were christened and then celebrated their first birthdays, Kalo provided her daughters with koloa to present to the pastors who officiated or otherwise prayed over and blessed the children. Her daughters were usually the ones to provide the cash part of these gifts. When her own younger sister, Tivinia, died of cancer in 2007, Kalo presented koloa to the pastors who prayed for and with her, and käinga for the safe passage of Tivinia's soul the Heaven. In 2010, when Sela's eldest daughter-and the oldest of Kalo's grandchildren - turned 21, the family threw her a large birthday celebration, and Kalo provided koloa for gifting to the relatives of the child's father and to pastors and other special guests who attended that occasion as well. When I saw her in early 2013, the most recent life ritual she had been involved in was the christening celebration organised by her great-niece, Anita, who had borne a baby boy several months before.

Exchanges like this take place regularly in both homeland and diasporic Tongan communities, and are crucial to the social status, expression of Tonganness and economic stability of Tongan families everywhere. At any given point in time, one or another member of a given käinga is in debt to someone in another käinga, and it is everyone's responsibility in the first käinga to contribute what they can-materially, spiritually and symbolically - to repay these debts. In receiving a reciprocal gift, kin groups incur further debt but also reaffirm the relationships between them. Focalwomen like Kalo tend to be experts in modelling to their relations how best to continue the cycles of reciprocity that have sustained them all materially and spiritually since they arrived in New Zealand. That said, wealth exchange can be contested and emotionally charged for these women, as well as for others in their community who benefit from the 'to- and fro-ing of [backcloth] and mats and things, [which] strengthens the relationships between family members' (Fanua 1996: 2). 
Tongans themselves often debate the utility of symbolic wealth exchange, when labour might 'best' be put towards earning money in the cash economy. Yet, histories of wealth exchange have continued to direct what Tongan exchange looks like globally today. Contemporary diasporabased relations are rooted in the homeland, for different kin groups were certainly interacting there before emigrating out. Thus, the who, rather than the where or even the when, of a history of exchange is what matters, even when individuals prefer to express cultural values by exchanging other valuables such as cash. It is from repeated acts of declaring one's identity as a Tongan through exchange that a sense of collective history, community and nation-building, both in Tonga and abroad, continue to be embedded in cultural wealth. Koloa, which historically have been made by groups of women, or at least by an individual woman working communally, are icons of this history. To women like Kalo, koloa, as a system of objects embedded in relations that span time and space, is thus inalienable-essential to Tongan identity (Addo 2013).

\section{Koloa and their wealth-like characteristics}

Anthropologists generally agree that it is through their associations with powerful people, deities and other efficacious entities that particular objects come to be considered wealth (Graeber 1996). Theorists of women's wealth in Tonga (Herda 1999; James 1997; Kaeppler 1999; Young Leslie 1999 and 2004) suggest that koloa are valued because of their origin in the hands of women and their association with the sacred status of women vis-à-vis their brothers. Women involved in koloa production imbue the cloths with womanly mana (sacred potency) when, working in groups, they hammer, paste, dye and pattern barkcloth from paper mulberry tree bark (Filihia 2001). Other important women's wealth items include large fine mats for gifting and waist mats called ta'ovala. These constitute smaller fine mats such as kie tonga, single-layered mats ( 1 metre by 1.5 metres [about 3 feet by 5 feet]) that are off-white in colour and decorated with brightly coloured, store-bought feathers and yarn. A special category of koloa, fala paongo, constitutes undecorated, twolayered mats of a medium-brown colour that women make from a special species of pandanus and that can be big enough to cover the floor of a large room (see Veys this volume). Also important in the koloa system 
are a variety of store-bought and machine-made quilts, bedspreads with matching pillow cases and decorated baskets filled with bottles of coconut oil, perfume and other toiletries (Herda 1999).

Phyllis Herda begins her 1999 essay, 'The Changing Texture of Textiles in Tonga', with this note: 'certain types of barkcloth and mats are categorized by Tongans as koloa, a term translated as (1) "wealth", (2) "possessions", (3) "what one values" (149), or prestigious objects (see Veys's designation, this volume). It is useful for analysts to think about the value of wealth items as a process of reinforcing, for oneself and others, just what it is that 'one values'. For Kalo, such a process is one in which women produce meaning from making, exchanging and influencing the lives of others with koloa. Through her bequests of wealth, Kalo intends to impart not just material value, but her entire outlook on and approach to contemporary Tongan life.

Kalo hopes her koloa will prove to be meaningful to the kin-group members to whom she has bequeathed them. Specifically, she hopes that her relatives will perform the meanings of koloa as cultural objects in the ways she has made them meaningful in her life and precisely because she has performed such value for them in her very acts of bequest. Some of these ways include using koloa as adornment for bodies, homes and ritual spaces; negating the relative fragility of textiles by purposefully keeping them as signs of the endurance of the kin group; employing koloa as a medium for compelling particular behaviours and sensibilities in others; using them to transmit efficacy from herself to others and from one generation to another; and trusting textiles to leave specific traces of herself through memories, associations, textures and smells evoked by or embedded in the koloa. Kalo characterises koloa as wealth because they afford her agency in ensuring that what she hopes for her kin-group members will indeed come true.

\section{Wealth adorns}

Koloa play a number of crucial roles in Tongan families' ritual life-stage events. Kin from both mothers' and fathers' sides gather to recognise each other's role in the celebrant's achievement of particular status. Individuals who attend are considered to be in a ritual state. They wear koloa, usually in the form of ta'svala, over their stitched clothing to contain their mana and as signs of respect for those with greater mana than themselves (Figure 38). Women like Kalo often embellish táovala in New Zealand (Figure 39). 


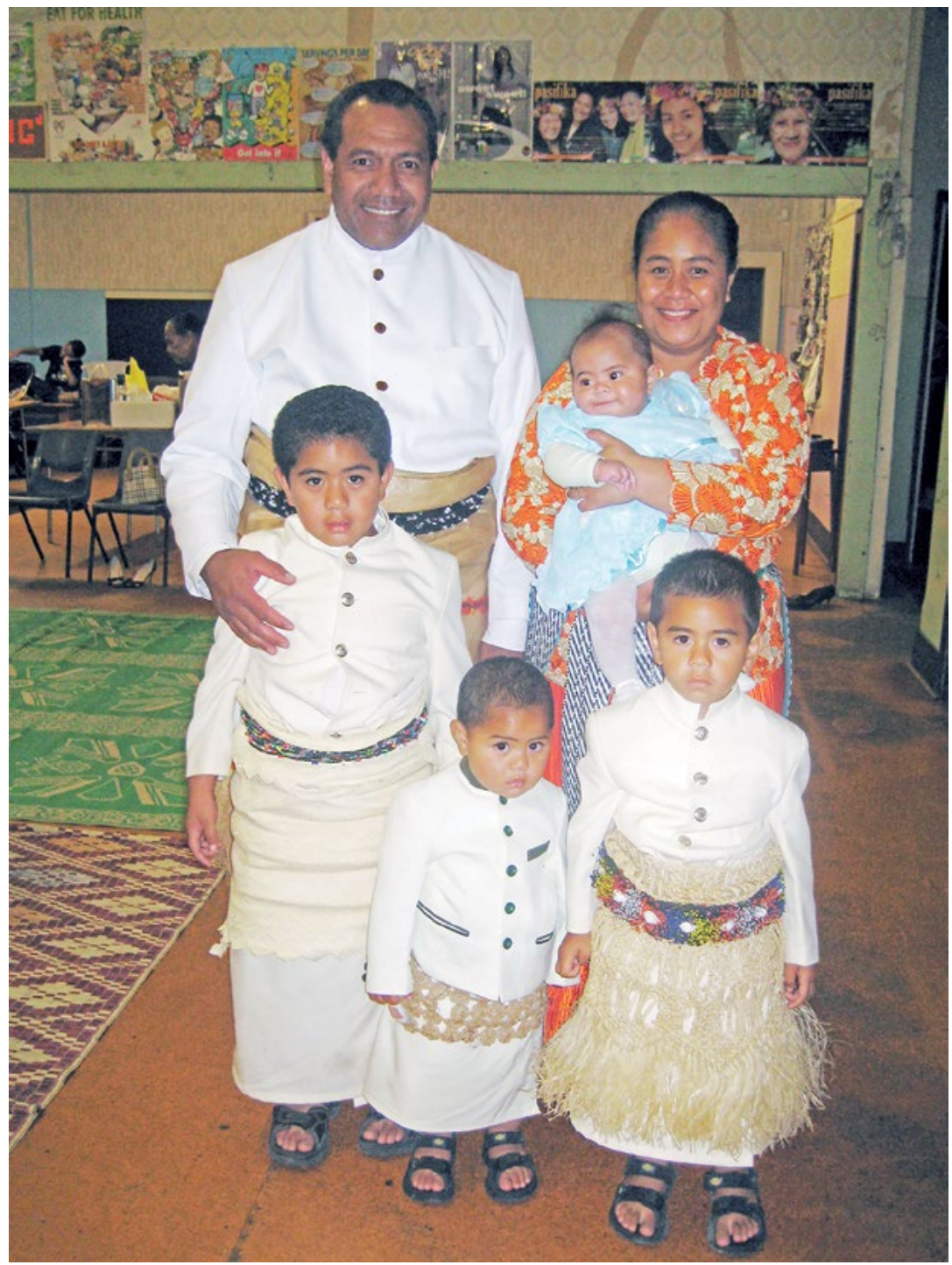

Figure 38. A family dressed for a special service at church. The father and three young sons are all adorned in ta'ovala (waist mats)

Source. Photographed by Ping-Ann Addo, Auckland, December 2007 


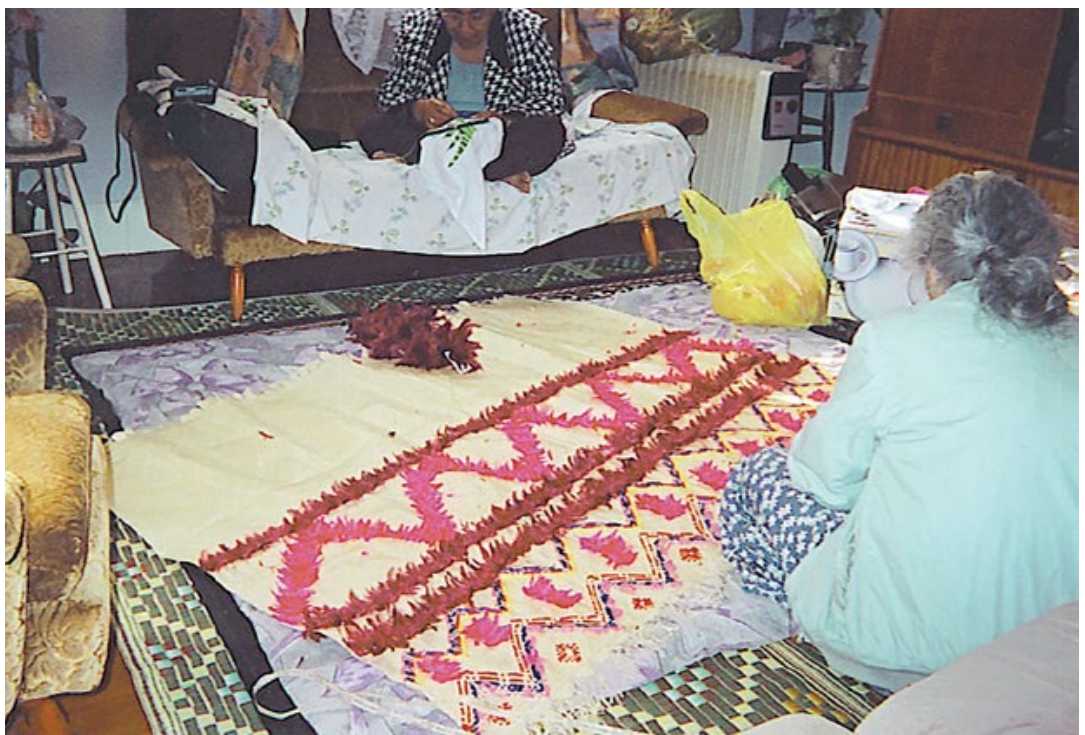

Figure 39. Kalo (seated at rear) and her textile group fellow work together on decorating a fine mat in her living room

Source. Photographed by Ping-Ann Addo, Auckland, August 2001

Women from a given kin group proceed into the gathering bearing fine mats and barkcloth, blankets and store-bought bedding. Sometimes they unfurl them for all to admire before they gift them, sometimes literally, at the feet of key members of a recipient's family. Finally, women will often have decorated the hall or space where the event is being held with koloa: barkcloth line the walls; fine mats line the floors under tables laden with Tongan food; durable pieces of koloa (like single-layer fine mats with brightly coloured yarn decorations) are draped over chairs where highranking guests like chiefly people and religious ministers will sit; and small gifts like cakes resting atop folded pieces of koloa are presented to certain guests (Figure 40).

David Graeber remarks on the commonality of wealth items being crucial to societal notions of value and performances of identity:

Insofar as wealth is an object of display, it is always in some sense an adornment to the person. In countless societies the most treasured forms of wealth consist of objects of adornment in the literal sense (Graeber 1996: 5). 


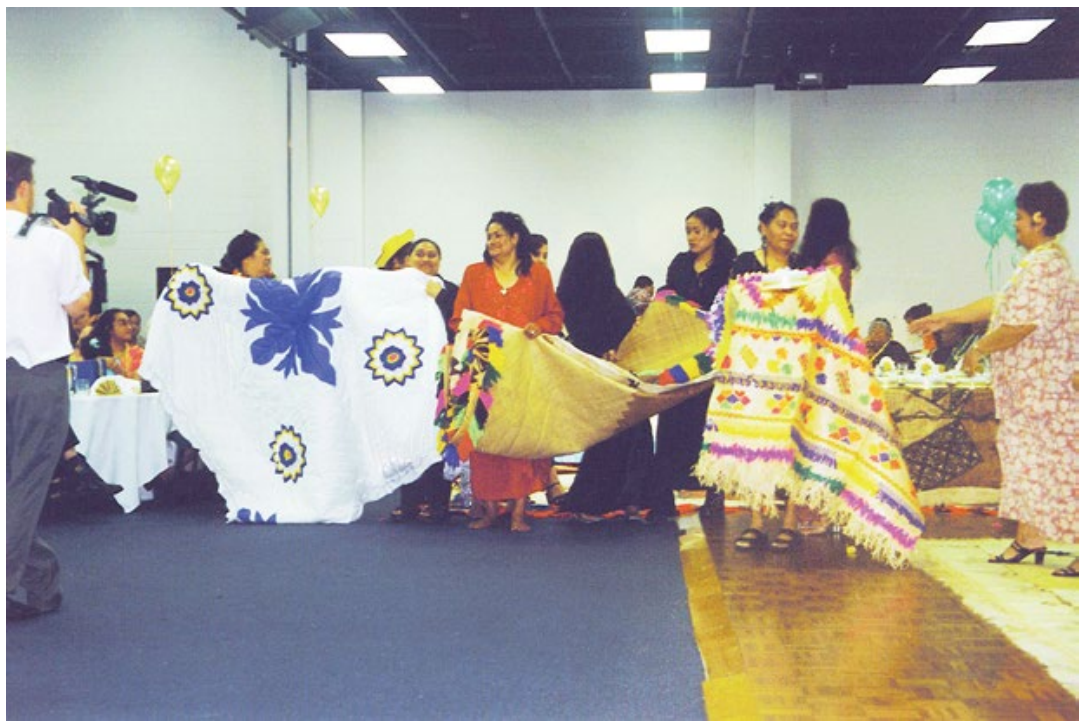

Figure 40. Koloa presented at Kalo's relative's 60th birthday celebration; note the barkcloth-covered tables at centre, fine mat-draped floor and chair at left, and cakes presented to honour guests at right

Source. Photographed by Ping-Ann Addo, Auckland, January 2001

Tongan women's textile wealth has been used to embellish people's homes, celebrations, lives and personhood, especially those of women, and they have done so for as long as Tongans can remember. Koloa have played a role as adornment in Tongan culture because they are things that Tongans have always used to visually announce their identity, values and sense of uniqueness and worth-ideal kinship relations, women's mana and women's work, mutual help and (the Kingdom of Tonga's) history. Koloa are thus, at a number of symbolic levels, 'privileged emblems of a group's identity' (Douaire-Marsaudon 2008: 213), embodying ideas about both cultural wealth and personal wealth. This idea that wealth can be visibly enacted as a sign of identity is no less true among Tongans in the diaspora.

\section{Wealth endures}

When I first interviewed Kalo in 2001, when she was 68 years old, she emphasised that she thought about what she could leave her daughters and grandchildren. Just as she raised her daughters, she has taught her grandchildren about their cultural responsibilities- to mind family and attend church. She said, at that time, that when she died she would want 
to leave them a sense of devotion to the (Methodist) church to which most of her family belongs, and 'whatever money' she had then. However, as long as I have known Kalo, cash is the resource that she is least likely to have on hand, for what little money she does have tends to be spent on buying textiles for use in religious and family functions, in addition to making donations to the church (Addo 2013: 108).

Often in Kalo's relationship to wealth, she would have very little money, but she could always fall back on traditional textile wealth if she needed to contribute to a collective family gift. Indeed, she had told me years ago that she preferred managing her relationships with koloa, traditional wealth, because 'cash just fell through her fingers'. Ten years after telling me she wanted to leave her children some cash, she was basically suggesting that money was neither the most important form of wealth nor the kind that had sufficient symbolic density to convey the efficacy she wanted to impart through her bequest. ${ }^{4}$

As long as Kalo has had koloa she could always keep track of her wealth and has never 'felt poor'. She chose, in this later stage of her life, to adhere to and pass down a form of wealth that could potentially endure over time: koloa. The endurance of koloa is entirely purposeful, for, like most textiles, if they are not assiduously maintained they may fade, rot, tear, be eaten (by pests) or pilfered away. As Annette Weiner states, 'Because cloth is subject to physical disintegration, keeping an old cloth despite all the ravages of time and the pressure to give it to others adds immeasurably to its value' (1989: 52). Furthermore, in families such as Kalo's, cloths are valued because they 'carry the histories of past relationships' (52), such as the relationship between Kalo and her mother.

Endurance of the physical form is a main characteristic of wealth everywhere (Sykes 2005), and there is deep meaning in the fact that wealth can potentially outlast those exchanging it at a given moment. Tongans value, source prestige from and basically have no social identity if they do not actively engage and maintain their kin ties by exchanging wealth. Thus, wealth endures so that käinga may materially and symbolically endure. That is, through the particular and directed deployment of wealth, a woman further enables her kin group to endure.

4 With the concept of symbolic density, Weiner (1994) suggests that some objects in a system of wealth items are relatively strongly associated with their owner's or custodian's 'fame, ancestral histories, secrecy, sacredness, and aesthetic and economic values' (394); they become weighty with cultural meaning and value and, thus, tend to be kept rather than given (away) in exchange. 


\section{Wealth compels}

A real turning point for the entire käinga occurred when Kalo's greatniece Anita announced she was going to give birth to her first child. The announcement came just a few months before Kalo moved into 'Ana's house. To the surprise of many people in the family, Kalo gave Anita two beautiful pieces of koloa - a fine mat and a barkcloth-before the baby's birth, with instructions that she, in turn, gift these to the baby's father's sisters. No one in Anita's generation had received koloa from Kalo directly; commonly in Tongan ceremonial exchange, koloa is gifted to someone of significance in the celebrant's lineage — in such a case it would be to the baby's father's sister, for example-and rarely to the celebrant herself. Yet, when I asked her why she had made such a gift to her greatniece, Kalo replied, 'Because she is going to be a mother soon'. The young woman would need wealth to exchange in order to legitimate her status as a Tongan woman and, moreover, as an appropriate mother.

Later, as her time to move to 'Ana's house drew near, Kalo began giving some of her other great-nieces and her granddaughters koloa as well. Yet, these koloa were meant to constitute more than an individual bequest of wealth. These cloths were valuables that-in Kalo's aspirations-were meant to maintain the status of the family. Kalo intended for the younger women to use them in ritual presentations that they would eventually participate in, and she instructed them on appropriate occasions and ways to gift them. The great-niece who had already born her first child had done so out of wedlock. Even though she was not married to the baby boy's father, the käinga was already engaged in reciprocal relations with his kin group. That they are Samoan-New Zealanders made this as appropriate as it would have been had they been Tongans; Samoan families similarly express their cultural values through exchanges of food, cash and textile. Known collectively as fa' alavelave, these ceremonies are similar to Tongan life-crisis ceremonies in marking ritual occasions with kin-based, public exchanges of ceremonial wealth (Gershon 2012).

When I asked Kalo why she gave koloa to the girls who were not yet mothers-why hadn't she waited until they had had their first children like Anita had-she replied: 'I don't want them to rush to have babies $\ldots$ and I might not be here when they become mothers'. With these gifts of koloa, Kalo meant to compel these younger women to be mothers in the same way that she had been a mother to their (biological) mothers. For the girls who were still without children, there was a deeper message: 
stay on the 'straight and narrow', don't get pregnant and finish school (four of the five girls in that generation were enrolled in or have graduated from the University of Auckland).

She said what she most hoped the younger women would do with the koloa was 'fai fatongia'; that is, present it ritually as gifts (literally: 'do duty'). She wished they could make koloa, but recognised that was an unrealistic expectation, as textile making was older women's work if it was done in diaspora at all (see Addo 2013). Thus, by passing textiles to them, Kalo was provisioning these young women to be generators of wealth in their own right. With these bequeathed wealth objects, she is compelling them to 'do duty'. In the past, I have seen Kalo work at imparting these younger women with knowledge about koloa — telling them how to fold and carry the things, as well as the order in which they should be laid out for presentation. They have always obeyed, encouraged by their aunts or their own mothers, and have usually done a satisfactory job. However, Kalo believes that they still require more knowledge and skill around choosing koloa, preparing them for gifting and gifting them in appropriate combinations at particular ceremonial occasions. Kalo intends to supply them with these skills with what remains of her life.

\section{Wealth transmits knowledge and efficacy}

Symbolically speaking, koloa is intimately tied to transmission of value, of knowledge and mana (Addo 2013; Herda 1999; Kaeppler 1999; Veys 2009; Young Leslie 2004). Meredith Filihia defines koloa as ancestral wealth and notes that the act of making koloa is itself a process of transmitting mana to people through things when the 'mana of ancient women is hammered into barkcloth' (2001: 387). Kalo constitutes, therefore, a crucial link in 'an unbroken line' between generations of Tongan women: their own ancestresses and the women their daughters, granddaughters and great-nieces would grow to be (381).

In this vein, Kalo had used a bequest of koloa to honour her ancestorsincluding her own mother from whom she initially acquired her notable knowledge of koloa - and to foreground her own impending status as an ancestor. Kalo has provisioned her younger women relatives with the wealth they need to do her proud now and after her death. To even the most devout Christian Tongans, ancestors are ever-present family memberspeople to be honoured and sometimes feared. It is my contention that what Kalo was trying to do was to compel and prepare these descendants 
of hers so that they could fulfill her desired destiny for them as cultural actors. The wealth objects bind them in ritual obligation to her, even after her death. Yet, if these younger women are to appropriately touch others with her mana through these cloths, then her opportunity to train them with the knowledge and skills to channel her efficacy is now.

Bequeathed wealth, when passed on, conveys a sense of stability both within the lineage and of the lineage (Brenner 2006), and thus it carries with it a sense that it has always existed. I use stability in both an abstract and a literal way. In the abstract sense, valuables must contribute to a notion of identity, culture and kin group as abiding and prompting people to think or respond 'we have always done it this way'. And in the literal sense: if a valuable does not feel like it will outlast the persons exchanging it, it is unlikely to be made to retain its status as the supreme form of wealth or to be given heirloom status. These are the roles that koloa had always played for Kalo. Indeed, the two pieces she had retained the longest were a fine mat and a barkcloth that her mother handmade many years ago in their village in Vava'u. Kalo had taken them to Auckland in 1978 when she first moved there, and she had kept these koloa for many decades, folded between sheets and other koloa under her mattress. A few other pieces that had belonged to her mother were among the koloa that she passed on to her younger kinswomen. The mana of Kalo's mother, the maker of these particular koloa, was part of her legacy to give to these younger women.

Thus, bequeathed objects also index death (the giver's) and are laden with many senses of obligation. By bestowing the wealth on them before her death Kalo can both compel her descendants to be givers of cloth and exemplify such giving to them. The cloths themselves are direct links to Kalo. They serve as reminders of her impending death, and are embedded with her mandate for the kin group to do right by her once she has passed away. Through simply passing on the cloth, Kalo hopefully leaves traces of herself and her desires that have effects across many generations.

\section{Gifted wealth leaves traces of the self}

When a woman launches knowledge and mana into the universe through her koloa, she also leaves traces of herself in the very physicality of cloth, as well as in associated memory and stories. As Suzanne Brenner states in relation to the gold that Sumbanese women pass on to their descendants, such a bequest constitutes an 'object of condensed value that literally 
and figuratively attaches to women' (Brenner 2006: 179). Some of the important works in the anthropology of the gift focus on the inalienabilty of objects/valuables in order to think about how (cultural) identities are established and augmented through the exchange of things as gifts (Kuehling 2005; Mauss 1990; Munn 1992; Strathern 1990; Weiner 1992; see also Hermkens and Lepani this volume). Yet Webb Keane (2001: 73) reminds us that wealth items (whether money or exchange goods) have multiple uses and possess features of mobility and durability, allowing them to extend the agency of actors, but also making them easily detachable therefrom. This quality of detachability is essential to wealthotherwise one could not actually exchange it for anything with anyone else-but it is not synonymous with alienability. As Weiner (1992) has argued, to give is not to alienate, but to reinforce connections through both giving and keeping. Even as women detach things from themselves in acts of giving, they create attachments to, or between, others. That which is kept purposefully is retained on behalf of lineages, communities and nations, for the longevity of their intertwined histories. Remember that Kalo kept koloa that her own mother had made in Tonga, specifically to be used as a wrapping for her corpse or coffin at her own death. Thus, intergenerational attachment and connection across space remain sources of value in women's lives.

Since these objects are acquired as gifts, they are also accompanied by obligations. While Kalo's provision of koloa, and her modelling of the actions around ceremonial gifting are only suggestions as to what she would hope for, they are bound up with the honour of the family. So rather than doing the work of arranging practically all aspects of the ceremonial gifting of koloa, Kalo has set up a situation in which younger members of her family would have to do right by her (even after her death) by showing their Tonganness with these koloa. Not only would they have to get involved in the intricacies of koloa-how to store and differentiate different pieces of the textiles, how to care for them, and how to match the quality of a piece appropriately to a specific celebratory event - they would have to actually gift the cloths. This is what she claims she explained to her great-niece when instructing the younger woman on how to prepare koloa for gifting at her baby boy's christening.

When a woman specifically leaves cloths with younger women-handpicking each cloth for a specific person to receive, with the intent that the recipient uses these wealth items for further exchange- she is actually projecting her own desires and intents vis-à-vis a wider community. 
My contention is that Kalo is clearly making claims on the resources, emotions and intentions of future generations of her family by locating herself as a key individual 'within [the] social networks' that will 'span generations' of their käinga (Young Leslie 1999: 259). She further indexes that although the specific koloa are no longer in her immediate possession and thus detached from her (see Keane 2001: 73), they remain identified with her. As such, these koloa are inalienable-at least in the younger women's mental, emotional and cultural associations. Thus Kalo will have agency after her death. As an ancestor, she will act through others, and her hope is that these young women in her kin group will become the primary enactors of her lifelong womanly compulsion to gift koloa.

\section{Conclusion}

In this chapter, I have looked at a life of gift prestation as well as at how the specific hopes of one elderly woman relate to the provisioning of her female kin-group members with women's wealth. Kalo's new role of provisioning and instructing younger women in her family to be able to maintain the family identity through gifting is a crucial part of who she has become towards the end of her life. I began with Kalo's life story in order to analyse the life course as a series of transitions between phases or stages in the ontogeny of a kin group. In so doing, I have been able to examine how and why a person may, over the course of her life, express the values embodied in textile wealth in highly contextualised yet enduring ways. There is no irony in this statement: koloa have divergent forms and meanings and, like all objects that serve as valuables, they have efficacy through humans' evolving relations with one another.

Writing at the intersection of käinga relations, gender and life course, I have argued that how women who gift wealth objects imbue them with efficacy and meaning can change over the givers' life course, based on their specific hopes for the recipient's future life course. People entrust that wealth items will do many things, such as materialise the idea that a kin group will endure, transmit efficacy, compel action and ultimately leave traces of the self. Thus, wealth can indeed have powerful effects on käinga members' identities and the relationships between them. However, we must understand the specific ways in which moments in the life course of people who give and receive wealth intersect in order to ascertain specific meanings and influential effects of wealth in moulding persons. Using the case study of a family I know well, I have focused on how an ageing woman 
uses koloa to guide her descendants, rather than on how she uses them to augment the reputation of her wider käinga, as she would do when she exchanges textiles with members of another kin group. Thus, I have also been able to examine exchange as a phenomenon that is as formative of how individuals relate within a käinga as it is of the family's status and reputation, which is normally based on exchange between käinga.

Descendants and textiles are among a woman's koloa, or 'what one values'. Since Kalo will one day die and leave behind both her descendants and her koloa, I have considered the ways that she connects these categories of valued entities together in her own mind based on the kinds of cultural lives she hopes her descendants will embrace. Looking at how Kalo prepares her kinswomen for a future she hopes will be filled with koloa exchange shifts the focus on socialisation away from life stages and rights-of-passage rituals to less temporally bounded, everyday relationships that women like Kalo have been cultivating with others. Over the typical Tongan life course, a person becomes connected cosmologically, politically, socially, religiously and culturally to others through the exchange of wealth, such that one commoner woman's life story has much to teach us about why and how people matter to each other, rather than why objects matter in themselves.

\section{References}

Addo, Ping-Ann. 2013. Creating a Nation with Cloth: Women, Wealth, and Tradition in the Tongan Diaspora. Volume. 4. ASAO Studies in Pacific Anthropology. New York, Oxford: Berghahn.

Albert, Steven M. and Maria G. Cattell. 1994. Old Age in Global Perspective: Cross Cultural and Cross National Perspectives. New York: G.K. Hall \& Co.

Berman, Tressa. 2003. Circle of Goods: Women, Work, and Welfare in a Reservation Community. Albany: State University of New York Press.

Brenner, Suzanne April. 2006. The Domestication of Desire: Women, Wealth, and Modernity in Java. Princeton: Princeton University Press. 
Counts, Dorothy Ayers and David R. Counts. 1985. 'Introduction: Linking Concepts, Aging and Gender, Aging and Death'. In Aging and Its Transformations: Moving Toward Death in Pacific Societies, ed. Dorothy Ayres Counts and David R. Counts, pp. 1-24. Pittsburgh: University of Pittsburgh.

Douaire-Marsaudon, Françoise. 2008. 'Food and Wealth: Ceremonial Objects as Signs of Identity in Tonga and in Wallis'. In The Changing South Pacific. Identities and Transformations, ed. Serge Tcherkézoff and Françoise Douaire-Marsaudon, pp. 207-229. Canberra: ANU E Press. Online: press-files.anu.edu.au/downloads/press/p90711/pdf/ ch10.pdf (accessed 18 February 2017).

Elder, G.H. Jr. 2001. 'Life Course: Sociological Perspectives'. In International Encyclopedia of the Social and Behavioral Sciences, pp. 8817-8821. Oxford: Pergamon.

Fanua, Tupo Posesi. 1996. Mãlō Tupou: An Oral History (as told to Lois Wimberg Webster). Auckland: Pasifika Press.

Filihia, Meredith. 2001. 'Men are from Maama, Women are from Pulotu: Female Status in Tongan Society'. Journal of Polynesian Society 110(4): 377-390.

Gershon, Ilana. 2012. No Family is an Island: Cultural Expertise among Samoans in Diaspora. Ithaca, NY: Cornell University Press.

Graeber, David. 1996. 'Beads and Money: Notes towards a Theory of Wealth and Power'. American Ethnologist 23(1): 4-24. DOI: 10.1525/ ae.1996.23.1.02a00010.

- 2001. Toward an Anthropological Theory of Value: The False Coin of Our Own Dreams. New York: Palgrave.

Herda, Phyllis S. 1999. 'The Changing Texture of Textiles in Tonga'. Journal of the Polynesian Society 108(2): 149-167.

James, Kerry. 1997. 'Reading the Leaves: The Role of Tongan Women's Traditional Wealth and Other "Contraflows" in the Processes of Modern Migration and Remittance'. Pacific Studies 20(1): 1-27.

Johnson-Hanks, Jennifer. 2002. 'The Limits of Life Stages in Ethnography: Toward a Theory of Vital Conjunctures'. American Anthropologist 104(3): 865-880. DOI: 10.1525/aa.2002.104.3.865. 
Kaeppler, Adrienne L. 1999. 'Kie Hingoa: Mats of Power, Rank, Prestige and History'. Journal of the Polynesian Society 108(2): 168-231.

Keane, Webb. 2001. 'Money is No Object: Materiality, Desire, and Modernity in an Indonesian Society'. In The Empire of Things: Regimes of Value and Material Culture, ed. Fred R. Myers, pp. 65-90. Santa Fe, NM: School of American Research Press.

Kuehling, Suzanne. 2005. Dobu: The Ethics of Exchange on a Massim Island, Papua New Guinea. Honolulu: University of Hawai'i Press.

Mauss, Marcel. 1990. The Gift: The Form and Reason for Exchange in Archaic Societies. London and New York: Routledge Classics. Original edition, Essai sur le don, first published 1950 by Presses Universitaires de France en Sociologie et Anthropologie.

Munn, Nancy. 1992 [1986]. The Fame of Gawa: A Symbolic Study of Value Transformation in a Massim Society. Durham, NC: Duke University Press.

Strathern, Marilyn. 1990 [1988]. The Gender of the Gift: Problems with Women and Problems with Society in Melanesia. Berkeley: University of California Press.

Sykes, Karen Margaret. 2005. Arguing with Anthropology: An Introduction to Critical Theories of the Gift. London: Routledge.

Veys, Fanny Wonu. 2009. 'Materialising the King: The Royal Funeral of King Taufa'ahau Tupou IV of Tonga'. The Australian Journal of Anthropology 20: 131-149. DOI: 10.1111/j.1757-6547.2009. 00007.x.

Weiner, Annette B. 1989. 'Why Cloth? Wealth, Gender and Power in Oceania'. In Cloth and Human Experience, ed. Annette B. Weiner and J. Schneider, pp. 33-72. Washington DC: Smithsonian Institution Press.

—_. 1992. Inalienable Possessions: The Paradox of Keeping-While-Giving. Berkeley, CA: University of California Press.

- _ 1994. 'Cultural Difference and the Density of Objects'. American Ethnologist 21(2): 391-403. DOI: 10.1525/ae.1994.21.2.02a00090. 
SINUOUS OBJECTS

Young Leslie, Heather. 1999. 'Tradition, Textiles and Maternal Obligation in the Kingdom of Tonga'. PhD thesis. Toronto: York University.

- 2004. 'Pushing Children Up: Maternal Obligation, Modernity, and Medicine in the Tongan Ethnoscape'. In Globalization and Culture Change in the Pacific Islands, ed. Victoria Lockwood, pp. 390-413. Upper Saddle River, NJ: Prentice Hall. 
This text is taken from Sinuous Objects: Revaluing Women's Wealth in the Contemporary Pacific, edited by Anna-Karina Hermkens and Katherine Lepani, published 2017 by ANU Press, The Australian National University, Canberra, Australia. 